University for Business and Technology in Kosovo

UBT Knowledge Center

UBT International Conference

2015 UBT International Conference

Nov 7th, 9:00 AM - 5:00 PM

\title{
The impact of air pollution on public lighting Solar panels in Shtimje
}

Vehbi Sofiu

University for Business and Technology, vehebi.sofiu@ubt-uni.net

Follow this and additional works at: https://knowledgecenter.ubt-uni.net/conference

Part of the Engineering Commons

\section{Recommended Citation}

Sofiu, Vehbi, "The impact of air pollution on public lighting Solar panels in Shtimje" (2015). UBT

International Conference. 46.

https://knowledgecenter.ubt-uni.net/conference/2015/all-events/46

This Event is brought to you for free and open access by the Publication and Journals at UBT Knowledge Center. It has been accepted for inclusion in UBT International Conference by an authorized administrator of UBT Knowledge Center. For more information, please contact knowledge.center@ubt-uni.net. 


\title{
The impact of air pollution on public lighting Solar panels in Shtimje
}

\author{
Vehbi Sofiu \\ UBT - Higher Education Institution, Prishtinë \\ vehebi.sofiu@ubt-uni.net
}

\begin{abstract}
Abstarct. Requirements for exploitation of renewable energy have occupied a special place in the world of developed technology; they carry in themselves the hope of a viable advanced possibility towards sustainable development. Kosovo has a favorable geographical position and favorable climate conditions for utilization of solar energy. Solar energy is a promising energy source of the future and it's use represents potential, since it is an inexhaustible natural source of energy, is the largest natural reserves of energy that is distributed throughout the world in quantities greater than our energy needs; is clean and it's use requires no additional cost, as well as does not expose risk to environmental pollution. The main focus of the assignment is, the impact of polluted air on the surface of solar panels, efficient energy use of sun to public street light in Shtimje. On the basis of analy sis of the current situation are presented three pillars, where for each pillar are presented the clarify ing objectives and for each geographic objectives are foreseen measures to realize their investment. Data on air quality through monitoring stations during are with completed data for all types of pollution occurring by $\mathrm{CO} 2, \mathrm{SO} 2, \mathrm{SO}, \mathrm{CO}, \mathrm{Nx}$, including $\mathrm{O} 3$ and PM 10 PM2.5 particles which have resulted that pollutants are of larger size and are influencing directly the efficiency of solar radiation that are represented in the form of smog on the solar panel surface creating shaped isolation layer.
\end{abstract}

Keyword: Solar Radiation, Smog of aerosol, Emition of $\mathrm{CO}_{2}$, Montioring air quality

\section{Introduction}

From all the research done so far it appears that Kosovo has the possibility to use the alternative resources, taking into account its geographical position as a key factor and the number of daily average hours of sunshine about $11.82 \mathrm{~h}$, in comparison to the competition in the market when the price of energy is cheap, or as the main problem when there is a lack of electricity or lack during the winter season due to the outdated power plants.

Today, Kosovo is faced with the need for clearly defined development goals with a long term strategy which will result in real demand for energy that would meet the essential needs of the household and industry for sustainable development .

This definition would also have major effects on employment of generations and economic development throughout the country.

In this paper, during the study discussion is focused on the current situation related to dealing of energy, obstacles from external factors for natural resource extraction of the sun, the better investment opportunities in this sector with sufficient radiant potential.

The current infrastructure, electricity imports, the construction of new energy capacity, renew able energy, energy efficiency, current problems evident in long-term planning that would solve the problem of power supply permanently.

The main focus of the assignment is, the impact of polluted air on the surface of solar panels, efficient energy use of sun and geographical possibilities of installing solar power plants without other influences of $\mathrm{CO} 2$ pollution and smog of aerosol, which can sensitively contribute to the security of electricity supply and thermal energy from the sun, in a power system for certain localities.

Data on air quality in Shtimje through monitoring stations with completed data for all types of pollution occurring by $\mathrm{CO} 2, \mathrm{SO} 2, \mathrm{SO}, \mathrm{CO}, \mathrm{Nx}$, including $\mathrm{O} 3$ and $\mathrm{PM} 10 \mathrm{PM} 2.5$ particles which have resulted that pollutants are of larger size and are influencing directly the efficiency of solar radiation 
that are represented in the form of smog on the solar panel surface creating shaped isolation laye[1-2].

\section{Measuring the radiation of the sun based on corners of sun-earth}

Passing the rays of the sun in empty space does not change the density of the spread radiant spectrum in relation to the square of the distance from the source of the solar radiation by the formula:

Where:

$$
\mathrm{E}_{\mathrm{o}}=\left(\mathrm{Rs}_{\mathrm{S}}^{2} / \mathrm{D}^{2}\right) \mathrm{ES}_{\mathrm{S}}
$$

ES - is the energy density on the surface of the Sun, which is set to black body radiation according to Stefan-Boltzmann's law $(6.3 \times 106 \mathrm{~W} / \mathrm{m} 2)$,

RS - is the radius of the Sun $(6,96 \cdot 108 \mathrm{~m})$, and

$\mathrm{D}$ - is the distance where is the estimated density of radiation from the Sun. For different planets now we can calculate the density of the radiation system according to Table 1.

Table 1: Constant solar radiation by planets

\begin{tabular}{|c|c|c|}
\hline PLANET & DISTANCE $\left(\mathbf{X 1 0} \mathbf{m}^{\mathbf{m}}\right)$ & $\begin{array}{c}\text { SOLAR } \\
\text { CONSTANT }\left(\mathrm{W} / \mathrm{m}^{2}\right)\end{array}$ \\
\hline Mercury & 57 & 9228 \\
\hline Venus & 108 & 2586 \\
\hline Earth & 150 & 1367 \\
\hline Mars & 227 & 586 \\
\hline Jupiter & 778 & 50 \\
\hline Saturn & 1426 & 15 \\
\hline Uron & 2868 & 4 \\
\hline Neptun & 4497 & 2 \\
\hline Pluton & 5806 & 1 \\
\hline
\end{tabular}

Source: Author+Y. Baghzouz, 2012

Extraterrestrial radiation is a radiation shown in the upper surface of the soil in the limits of the atmosphere.

The distance of the Earth from the Sun varies over the years and extraterrestrial radiation varies from a minimum value of $1321 \mathrm{~W} / \mathrm{m} 2$ to $1412 \mathrm{~W} / \mathrm{m} 2$ greater, while the standardized constants of sun radiation is $\mathrm{I} 0=1367 \mathrm{~W} / \mathrm{m} 2[3]$.

The perpendicular solar radiation of the extraterrestrial surface calculated for a day of the year is determined by expression:

$I_{0 j}(j)=\varepsilon(j) \cdot I_{0}=\left(1+0,03344 \cos \left(\frac{2 \pi j}{3 \cos 65,25}-0,048869\right)\right) I_{0}$

$\mathrm{I}_{0}$ - is the sun constant,

$\varepsilon$ (j) irregular rotation in the orbit of the Earth,

$\mathrm{j}$ - ordinal number of days $(\mathrm{j}=1,2,3,4,5, \ldots \ldots \ldots \ldots . . .365)$

Solar radiation in the horizontal plane can be calculated from the extraterrestial surface of the perpendicular sun radiation towards the direction of the earth:

$I_{o h}=I_{0} \varepsilon \cos \zeta_{S}\left[{\frac{W^{2}}{m}}^{2}\right]$

A general case for a time interval from $\omega_{1}$ to $\omega_{2}$ : 


$$
\begin{aligned}
& G_{0(12)}=I_{0} \varepsilon \frac{T}{2 \pi}\left[\sin \emptyset \sin \delta\left(\omega_{2}-\omega_{1}\right)+\cos \emptyset \cos \delta\left(\sin \omega_{2}-\sin \omega_{1}\right)[J /\right. \\
& \left.\left.m^{2}\right]\right]
\end{aligned}
$$

-The values in each hour, $\left|\omega_{2}-\omega_{1}\right|=\pi / 2$ me $\zeta S>0$ during the hours:

$\mathrm{G}_{0 \mathrm{~h}}=\mathrm{I}_{0} \varepsilon \frac{T}{2 \pi}\left[\sin \emptyset \sin \delta \frac{\pi}{2}+\cos \emptyset \cos \delta\left(\sin \omega_{2}-\sin \omega_{1}\right)\right]\left[J / m^{2}\right]$

( 2.5 )

-Daily value, $\omega_{1}=\omega \mathrm{S}, \omega_{2}=\omega \mathrm{S}$ :

$G_{0 h}=I_{0} \varepsilon \frac{T}{2 \pi} \cos \emptyset \cos \delta\left(\sin \omega_{s-} \omega_{s} \sin \omega_{s}\right)\left[\mathrm{J} / \mathrm{m}^{2}\right]$

Parameter T equation (2.10) is the duration of the Earth's rotation around its own axis, $\mathrm{T}=86400 \mathrm{~s}$ $(24 \mathrm{~h})$. When irradiation values are used the symbol $\dot{G}_{o(12)}$ replaces $\mathrm{G}_{0 \mathrm{~h}}$ to indicate average values[4].

\section{Photos ynthesis and photovoltaic solar energy}

Much of the chemical energy produced by life forms, such as cases of burning fossil derived from the use of solar energy through photosynthesis. Solar energy is produced by thermonuclear fusion process in the core of the Sun. Radioactive isotopes used as fuel in nuclear power plants. Food supernova is a type of fuel for which humans and animals need. Solar Energy supports almost all life organisms on earth through the photosynthesis process since the first ap pearance of the organisms when people use solar energy for lighting, warmth, growth of crops and the conversion of the radiation of the sun into electricity.

Heat produced by sunlight determines climate and changing of seasons on earth. Solar cells are semiconductor materials that convert sunlight directly into electricity [5].

The conversion of solar energy into electricity energy otherwise called Photovoltaic (PV). The process can repair photosynthetic activity of sun-catching cellular molecules and put them in use, scientists and engineers are looking for their activities to create more and more solar energy efficiently. The sun is the star at the center of our solar System. Earth and other celestial bodies of our solar system (including planets, asteroids, meteorite, comets and cosmic dust) rotate around the sun. The sun represents $99 \%$ of the mass of our solar system. Solar Energy supports almost all life on earth through photosynthesis since the emergence of the first body an imitator of photosynthesis. People use solar energy for lighting, warmth, growth of crops and conversion of solar power into electricity. Warmth produced by the sun sets climate (weather) and change of seasons on earth. Astronomical signs of the sun are about $73 \%$ of mass of the sun, hydrogen, helium is $25 \%$, and the remainder consists of small amounts of heavier elements[6].

\section{Lighting with LED lights in Shtimje}

Practice has shown that quick and effective solution is the use of photovoltaic technology which directly reduce energy costs and in the future will save a lot of money, direct and indirect (fixed consumption of electricity by network).

In Table 2 are presented the technical parameters of LED lighting in normal working conditions for public street lighting. 
Table 2: Characteristics of LED lights and lighting fixtures.

\begin{tabular}{|c|c|c|c|c|c|}
\hline Surface & $P[\%]$ & $\begin{array}{c}\text { E aver. } \\
{[1 \mathrm{x}]}\end{array}$ & $\begin{array}{c}\text { E min } \\
{[1 \mathrm{~lx}]}\end{array}$ & $\begin{array}{c}E \max \\
{[1 \mathrm{x}]} \\
\end{array}$ & $M_{0}$ \\
\hline Workplane & / & 72 & 21 & 113 & 0.29 \\
\hline Floor & 20 & 67 & 27 & 86 & 0.41 \\
\hline Ceilings & 60 & 33 & 11 & 226 & / \\
\hline Walls & 30 & 54 & 19 & 114 & I \\
\hline \multicolumn{3}{|c|}{ Designation (Correction factor) } & $\Phi[\mathrm{lm}]$ & $\mathrm{P}[\mathrm{W}]$ & \\
\hline SITECO & $5 \mathrm{LS} 2281-1 \mathrm{C}$ & FR 100 & 4550 & 50 & \\
\hline
\end{tabular}

Modules are installed in conformity with the eligibility test regarding the use during installation, and also resistance to all weather factors such as wind, rain, snow, etc. Solar panels are installed on the roof of metal pillar reinforcement structure. Holders of panels are isolated and do not allow the entry of water from rain or melting of snow. Battery is destined to save up and supply with electricity in a timely manner, without the need for maintenance, and the lead-acid batteries of $120 \mathrm{Ah} / 12 \mathrm{~V}$ - two units are located in box.

Controller/regulator is to optimize the charging/discharging process of the battery and to extend its lifetime. Battery status is reflected as an indicator in a liquid crystal. The function of the regulator is to protect the system from short circuits, free flow, the process excessive charging/discharging. The microprocessor controls the loading and temperature compensation of determining the level of charging (stuffing)[7].

Electrical installations as part of the solar system between the solar panels, battery and regulator of $2 \times 2.5 \mathrm{~mm} 2$ conductor.

Data on solar panel with power of $80 \mathrm{Wp}$ are presented in Figure 33, which are installed in

Fushkosova, Shtimje and Prizren have a MAXIMUM of electricity intensity of $3.45 \mathrm{~A}$ in average and optimal conditions of the sun's rays and zero impacts of pollution, in contination are presented the data on solar panels:

Model of SSLD55W illuminating body:

Solar modules: 80Wp / 12VDC,

Solar module support structure: 80Wp / 12VDC,

Battery: free-held lead-acid baterry of $100 \mathrm{Ah} / 12 \mathrm{~V}$,

Battery box: 2pcs 100Ah/12VDC,

Controller: $15 \mathrm{~A} / 24 \mathrm{VDC}$,

Light source: High street lamp of 55W/12VDC,

Lumen: 5400-6000 LM,

Installations and other materials,

Metal pole: 8 - $9 \mathrm{~m}$,

Working temperature: $-40^{\circ} \mathrm{C} \sim 55^{\circ} \mathrm{C}$,

Wind-stand $>120 \mathrm{kmlh}$,

Operation time: 10-12 hours/day,

Three days raining. 
Measuring the intensity of the current and voltage is made by direct electronic measurement with the

FLUKE instrument type, and the measured values are presented in Table 3 [8].

Table 3: The measured intensity values of current and voltage when the panel is polluted.

\begin{tabular}{|c|c|c|c|}
\hline Place & $\begin{array}{c}\text { Temperature / } \\
{ }^{\circ} \mathrm{C}\end{array}$ & $\begin{array}{c}\text { Currents / Ip } \\
\text { ( DC A) }\end{array}$ & $\begin{array}{c}\text { Voltage / Up } \\
\text { (DC V) }\end{array}$ \\
\hline Shtimje & 27 & 2.6 & 28.7 \\
\hline
\end{tabular}

Source: Author, 2014

\section{Evaluation of pollution by particles of mate rials (PM)}

PM are generated by a range of different particles arising from different types of sources. Concentrations of PM include mainly particles directly emitted into the atmosphere from burning sources and secondary particles formed by chemical reactions in the air.

Particulate matters (dust) are generated by natural and anthropogenic processes, which are distributed in the form of diffusive air and fall to the ground or under the influence of gravity along with the atmospheric rain. In the Republic of Kosovo, the largest source of PM pollution, caused by human factor is large combustion plants such as power plants, Ferronickel smelter, production of cement, transportation, industrial wastelands, etc.. Dust alway s contains particles from the ground, one of the factions of dust are emitted by: cars, pedestrians and wind on land. Various particles also appear from industrial processes. The concentration of flying particles depends on meteorological conditions during the day and over the seasons [9].

The presence of particles in the air has significant impact on public health. It is known that some substances in the atmosphere that are in the form of particles or aerosols are as polynuclear aromatic hydrocarbons that can cause cancer. Particles affect the intensity of solar radiation that reaches the earth. The particles can also affect various materials accelerating corrosion (oxidation) of metals. Secondary particles of PM formed by emissions of ammonia, sulfur dioxide, nitrogen oxides and organic compounds emissions are derived from two sources, those with burns and vegetation. In continuation, we'll illustrate the measurement of particulate pollutants taken in samples for several periods at the same time and in different seasons $[9-10]$.

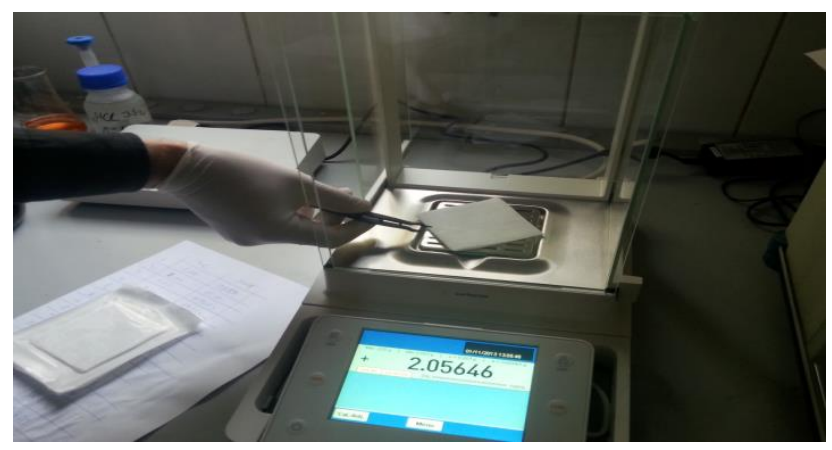

Figure 1: Sterile bandages without pollution.

Source: Author, 2014

The measurements carried out in the laboratory are presented digitally by SARTORIUS instrument indicating that the weight of sterilized bandage is without pollution, as presented in Figure 1. 


\section{Conclusions}

Solar panels placed on public road in Shtimje are subject to the study of current and voltage intensity and the amount of pollution collected on the surface of solar panels. From measurements performed in Shtimje, solar radiation is $1622 \mathrm{kWh} / \mathrm{m}^{2} / \mathrm{y}$ ear. The measured particles of aerosol pollution on the surface of solar panels for panel module are expressed in grams and measurements are made with Sartorius $225 \mathrm{~S}$ instrument. In Shtimje is concluded that there are aerosol contamination and are influential in reducing the sun's rays. These pollutants are the main ingredient of aerosol effects, which are all also harming the environment and the reactions have impact on environment protection.

The height of sea level, geographic location to east from the sea, without pollution of emissions by aerosol combustion are also the exploitation of the resource advantage of the sun with $100 \%$ efficiency, and therefore, are not affected by the effect of aerosols[10-11].

\section{References}

1. Ministria e Mjedisit dhe Planifikimit Hapesinor, Agjensioni per Mbrojtjen e Mjedisit te Kosoves,Gjendja e Mjedisit ne Kosove 2008- 2010, Prishtine 2011.

2. Raport: Zhvillimi dhe vlerësimi i op sioneve për furnizim me energji elektrike në Kosovë, dhjetor, 2011, Prishtine.

3. Kasthurirangan Gopalakrishnan \& Siddhartha Kumar Khaitan \& Soteris Kalogirou, 2010, Soft Computing in Green and Renewable Energy Systems, Berlin Hidelberg.

4. ITACA, Part 4: Irradiation Calculassions, Sections: Solar Photovoltaics, 2012) http://www.itacanet.org/the-sun-as-a-source-of-energy/part-4-irradiation-calculations/

5. Energy and Climate Change, Professional Development Workshop Materials, 2006-2007).

6. Antonio Luque \& Steven Hegedus, Handbook of Photovoltaic Science and Engineering, 2003, United Kingdom).

7. ITACA, Part 2: Solar Energy Reaching The Earth's Surface, The Sun As A Source Of Energy, Sections: Solar Photovoltaics, 2011.

8. Sofiu V: Research Inventy: International Journal Of Engineering And Science Issn: 22784721,Vol.2,Issue 6 (March 2013),Www.Researchinventy.Com

9. (MMPH), Draft Strategia dhe Plani i Veprimit për Cilësinë e Ajrit, 2011, Prishtine.

10. Vlersimi Strategik Mjedisor I Planit zhvillimor Urban Te Prishtines 2013-2023, pp4, Gusht 2013.

11. Raport per Gjendjen e Ajrit, Ministria e Mjedisit dhe Planifikimit Hapsinor, Agjencioni per Mbrojtjen e Mjedisit ne Kosove, Prishtine, 2012. 